\title{
Challenges Facing Effective use of Bat Guano as Organic Fertilizer in Crop Production: A Review
}

\author{
Ernest Melkiory Marwa ${ }^{1 *}$, Twisege Andrew ${ }^{2}$, Asha Ally Hatibu ${ }^{3}$
}

\begin{abstract}
Bat guano is excrements of bats and it is commonly used in agriculture as a soil amendment and sometimes as a pesticide in organic farming. Small-scale farmers nearby guano deposits use it for indoor and outdoor plants as well as for hydroponic crop production. Guano in soils acts as a source of carbon $(C)$ and energy to drive microbial activities as well as a precursor to soil organic matter fractions. With all these benefits, bat guano should be used in crop production with some precautions. Chemical composition and properties of bat guano are not fixed and are changing with time depending on the maturity, reaction with the country rock and bat diet. The pH of guano changes from alkaline to strongly acid with maturity. Similarly, guano loses some essential plant nutrients on decomposition and sometimes acquires potentially toxic elements as it reacts with the host rocks. Amounts added to the soil also vary with maturity and composition of guano. Thus, utilization of bat guano as organic fertilizer requires a thorough and regular characterization at the time of using it as soil amendment for crop production.
\end{abstract}

Keywords: Bat guano, nitrogen, phosphorus, organic fertilizer

\section{INTRODUCTION}

Bat guano is excrements of bats and is commonly found in isolated islands and in caves [1]. Many studies indicate that bat guano is enriched with both macro-and micronutrients that are required by plants in natural form [1], [2]. In soil, guano acts as a source of carbon (C) and energy to drive microbial activities as well as a precursor to soil organic matter fractions. On decomposition, it releases a number of essential plant nutrients and also it controls the net mineralization-immobilization patterns in the soil [2]. However, its chemistry is highly variable. It contains a varying amount of nitrogen $(\mathrm{N})$, phosphorus $(\mathrm{P})$, calcium $(\mathrm{Ca})$, magnesium $(\mathrm{Mg})$, potassium $(\mathrm{K})$, aluminium $(\mathrm{Al})$, iron $(\mathrm{Fe})$ and sulphur (S) [3]. Other elements such as fluorine $(\mathrm{F})$, chlorine $(\mathrm{Cl})$, copper $(\mathrm{Cu})$, manganese $(\mathrm{Mn})$, molybdenum (Mo), nickel (Ni), zinc ( $\mathrm{Zn})$ and cadmium (Cd) occur in low concentrations. Presence of these elements in guano is associated with the reaction between the surrounding rocks (cave wall) and guano solutions. Most of these elements exist in guano as compounds [4], [5].

Guano tends to generate secondary minerals that are beneficial to plant on decomposition. Formation of secondary minerals such as gypsum and phosphate rocks help in a long-term availability of nutrients to plants as these minerals decompose and release nutrients slowly, hence are of high residual value. Harmful materials such as urea, which are due to high concentration of urine, can be volatilized and toxic bases such as sodium and aluminium can be leached with time. Immature (fresh) guano has little variations in nutrients concentration due to poor formation of secondary minerals as a result of low decomposition [6].

In agriculture, guano is reported to be useful in a number of ways, such as fertilizer material due to high content of nitrogen and phosphorous [5], [7]. It is reported to contain $2-6 \%$ total nitrogen, $1.5-10 \%$ available phosphoric acid and 1.5-10\% soluble potassium [8]. The concentrations of $\mathrm{N}, \mathrm{P}$ and $\mathrm{K}$ in bat guano meet the 5\% N P K composition set as criteria for any material to qualify as a fertilizer [4]. It can act as a soil building material, fungicide (when foliar fed to plants), control of nematodes through attracting decomposers which work as biological control agents against nematodes, as well as a compost inoculants/activator [9], [10].

Microbes found in guano act as soil cleansers (bioremediation microbes) that help to clear up toxic residues, control root pathogens such as nematodes; and some microbal species such as Aspergillus and Penicillium spp are known to produce strong mycotoxins (biochemicals) [11] that repel other microorganisms such as bacteria, protists, nematodes and dangerous pathogens in the soil [12]. That is why guano can be used as pesticide in crop production system. With respect to all benefits listed above, guano remains a key resource of nutrients for organic farmers, especially small-scale farmers nearby guano deposits where it can be used for indoor and outdoor plants as well as for hydroponic crop production.

Although guano can be used as organic fertilizer, it requires characterization to assess its suitability for agricultural uses at the time of application to ascertain its physic-chemical properties and whether or not they contain potentially toxic elements (PTEs), which could be of health and environmental concern.

\section{SOME CHALLENGES WITH BAT GUANO \\ Variation in Chemical Composition}

There are different factors that determine the composition of bat guano. These factors are nutritional habit of the bat, age of guano in the cave (guano maturation), amount of water in the guano, the intrusion of other materials from outside the cave, and the composition of the bedrock forming the floor and the surrounding host rocks of the cave. Thus, chemical composition of bat guano is not fixed, it varies with time and surrounding environment of the cave. 
There are some contradictions between scholars on their studies on guano based on the nutritional habit of the bats. According to [6], insect eating bat guano has larger amount of phosphorus than fruit eating bat guano; and protein containing foods are richer in phosphorous than fruits. On the other hand, [13] and other colleagues emphasize that insect eating bat guano has higher nitrogen than fruit eating bat guano which also was stated by [14] and [15].

According to [16] night bats consume about half of their own body weight, and the rate of faecal production and composition reflects the rate of biomass ingested. Minimal or inadequate ingested level for a given element would initiate physiological mechanisms which maximize assimilation of that element and, therefore, minimize faecal concentration of that element [17].

Variations in faecal element levels were observed within sex [17]. This variability was suggested to reflect differences in physiological status (assimilation efficiencies in males and females), highly variable composition of insects available as opportunistic prey items, or poor selective feeding by the female and male bats. A study done on female and male big brown bats indicates that there is a significant decrease in faecal level concentrations of potassium, calcium, iron and magnesium except sodium, over the summer; but for female there were no variations due to time in season except for calcium, which increased over time. For the nitrogen element, guano from both sexes contained similar levels [17].

The chemistry of guano is also influenced by its age. With time in the cave, guano continued to acquire some additional elements leaching from the surrounding host rocks. Thus, old and young guano both differ in their chemical composition. According to [6] fresh bat guano contains organic matter and total carbon content higher than in humus guano. Nitrates and sulphates are higher in young guano (faecal pallets) than in mature guano while calcium, potassium, aluminum, iron, magnesium, bacteria, actinomycetes and fungi are higher in humus-like guano than in faecal pellets. On the other hand, phosphates are said to be high in both faecal pellets and humus guano [6], [13]. This could possibly be because phosphorus is found in the fresh food eaten by bats (fruits, insects and mammals) and also in secondary minerals formed in the caves after guano solution has reacted with cave wall or bedrock. Thus, composition of bat guano varies with maturation.

Where there is no water entering the cave and the atmosphere is sufficiently humid to promote bacterial decomposition, guano is likely to contain high nitrates, potash, phosphoric acid, and soluble salts or a product richer than the fresh guano, due to the decomposition of the bulky organic matter. Totally dry conditions, where moisture is deficient for much bacterial decomposition, will most probably produce guano with nearly the same composition as the faecal pellets due to low, if any, microbial activities [18].
The amount of water entering the cave does affect the material more than any other condition. This is because the soluble constituents are leached down to the bedrock. This causes phosphates and sulphates to react with the bedrock, leading to the loss of potash and nitrates in drainage water [6]. However, if water that enters the cave contains very little soluble material, and if only a small amount of water infiltrates through the host rock, that guano may contain considerable soluble phosphates, gypsum, some nitrates, and ammonia from the rock. Leached phosphatic guano may become enriched temporarily by the infiltration of soluble phosphates, nitrogen and gypsum from other parts of the cave. The accumulations of gypsum, which sometimes occur in certain parts of a cave, are obviously due to the evaporation or leaching from other parts of the caves [18] - [20].

Apart from the translocation and removal of soluble materials, water affects the composition of guano by influencing the course of bacterial decomposition. When fresh guano is so saturated with water and becomes covered with a crust of carbonate of lime or a slide of other guano it undergoes anaerobic bacteria decomposition [18].

The character of the rock forming the cave determines largely the composition of the leached or phosphatic guanos. Where the cave is formed in pure limestone guano consists mostly of tricalcium phosphate [6], [18]. Where the rock contains considerable amounts of iron, aluminium, and silica, these elements are brought in by water; that guano may consist largely of phosphates of iron and aluminium with siliceous impurities [21], [22]. Thus, the chemistry of the surrounding host rock can determine the composition of bat guano, particularly when it contains soluble minerals that can be leached easily.

Occasionally earthy materials may be carried into the cave through the mouth of' the cave or through holes (openings) in the ceiling. When these materials from outside the cave become admixed with the guano, they decrease its value [18]. According to reference [20] some materials such as pollen found in the guano of insectivorous bat may be brought in the cave through air, seepage, animals or by night-flying bats and insects meet them in the atmosphere.

\section{Variability in Nutrient Contents}

Nutrient contents in bat guano is a function of various factors including geographical location where the bats and hence guano is found, bat specie, guano age, type and form of caves where bats live and type of diet taken by bats [23], [24]. Reference [17] during summer roosting period they analyzed nitrogen, sodium, calcium, magnesium, iron and potassium levels in faeces of some neotropical bats. They reported that $\mathrm{N}$ levels were markedly higher while $\mathrm{Na}$ levels were marginally higher in faeces of carnivores and omnivores than in frugivores. Calcium levels were higher and potassium levels were lower in faeces of insectivores. Also, they reported that total iron levels in faeces of frugivorous species were marginally lower than in 
carnivores or omnivores furthermore $\mathrm{Mg}$ concentrations was imbalanced in all feeding habits.

Table 1 : Variation of some plant nutrients in Sukumawera and Kisarawe bat guano in Tanzania

\begin{tabular}{|c|c|c|c|c|}
\hline \multirow{2}{*}{ Nutrient } & \multicolumn{4}{|c|}{ Amount, \% } \\
\cline { 2 - 5 } & SI & SO & KI & KO \\
\hline $\mathrm{P}$ & 40.67 & 20.32 & 14.85 & 7.38 \\
\hline $\mathrm{K}$ & 5.53 & 5.18 & 5.39 & 4.31 \\
\hline $\mathrm{Ca}$ & 5.83 & 6.04 & 6.54 & 3.62 \\
\hline $\mathrm{Mg}$ & 0.19 & 0.18 & 0.19 & 0.19 \\
\hline $\mathrm{Ni}$ & 0.04 & 0.01 & 0.01 & $<0.01$ \\
\hline $\mathrm{Mn}$ & 1.44 & 0.64 & 0.9 & 0.68 \\
\hline $\mathrm{Zn}$ & 1.57 & 0.63 & 0.48 & 0.59 \\
\hline $\mathrm{Cu}$ & 0.47 & 0.14 & 0.11 & 0.12 \\
\hline
\end{tabular}

$\mathbf{S I}=$ Sukumawera bat guano found inside the cave; $\mathbf{S O}=$ Sukumawera bat guano found near the opening of the cave; $\mathbf{K I}=$ Kisarawe bat guano found inside the cave and $\mathbf{K O}=$ Kisarawe bat guano found near the opening of the cave.

Reference [25] also observed big variations in nutrient contents in bat guano from Sukumawera and Kisarawe (Table 1). Both guanos are from Tanzania and are about $600 \mathrm{~km}$ from one another. Guano nutrient contents inside and outside the caves were also different. In Kisarawe guano, total P level was lower as compared to that from Sukumwera; presumably because this guano was relatively younger than that of Sukumawera guano, so it was less decomposed and hence poor formation of phosphate minerals. However, the amounts of P in Sukumawera and Kisarawe bat guano were relatively higher compared to the average amounts of $2 \%$ to $7 \%$ as reported by [26]. Similarly, the amounts of $\mathrm{P}$ reported by [25] were higher than in Makindu bat guano in Kenya that had 3 to 6\%, insectivorours bat guano found in Assaigolli village cave (0.8 to $3.7 \%$ ) and Chipongwe cave guano in Zambia $(4.03 \%)$ but bat guano outside Kisarawe cave (KO) had low P (7.38\%) than Kapongo cave guano in Zambia (8.41\%) [1], [8], [13]. This implies each deposit has different levels of nutrients and also nutrients in the same deposits vary depending on where the sample is taken.

This variation is presumably due to many factors including change in nutritional habit of the bats as opportunistic prey, loss through leaching and some chemical reactions that take place in the caves as time goes [6], [13], [22]. For instances, analysis done in 1961 and 2004 on the Kapongo cave guano in Zambia revealed that guano had changed from rich in nitrogen to rich in phosphorus [8].

Nitrogen, $\mathrm{K}$ and $\mathrm{Mg}$ in guano appeared to be adequate for crop production for bats of all feeding habits. References [26] and [27] reported that the guanobitic and guanophilic arthropods community was observed that guano contained high NPK content which help to improve soil quality and provide nutrients for plant growth. Reference [13] analyzed nutrients in bat guano (total nitrogen, phosphorus and potassium) and found higher nitrogen levels than phosphorus. The NPK was higher in fecal pellets than in humus guano 7.9:2.4:1.1 and 5.7:2.2:0.9, respectively. In comparing with other animal manures (poultry, cow and sheep manures) [28] reported that bat humus guano was higher in nitrogen and total carbon was lower resulting in narrow $\mathrm{C} / \mathrm{N}$ ratio, while phosphate was more than in cow and sheep manures.

Reference [29] reported 84.3, 88.4 and $88.8 \%$ of organic matter in guano produced by bats feeding on insects, blood and fruits, respectively. Studies by [6] conducted in Israel reported organic matter contents of $60 \%$ and $53-65 \%$ in guano produced by bats feeding on fruits and insects, respectively. From India, [13] reported $45.6 \%$ organic matter content in insectivorous bat guano.

In addition to variations due to bat species, the diets and geographical regions, organic matter content of guano deposit also varies with depth where the topmost centimeters (usually partially decomposed) have the highest organic matter content. Organic matter content declines with depth, and is generally completely decomposed within the top few metres [6], [30]. Upon decomposition of organic material in the deposit, much of the carbon is consumed and nitrogen is released. The remaining, largely acidic, guano materials interact with weathered material in the cave to form new largely phosphatic, authigenic (secondary) minerals with other elements such as aluminum, potassium and iron from the guano [22], [6].

\section{Nutrient Release from Bat Guano}

Nutrients in guano are not readily available for plant uptake as reported by many scholars. They are gradually released in soil on decomposition. Recent study done in Tanzania indicates that guano releases $\mathrm{P}$ in the soil gradually and reaches the pick 84 days after application [31]. It implies that to make effective utilization of P released from guano, it should be applied in soils at least two months before planting, to enable the released $\mathrm{P}$ to be available in adequate amounts for plant growth. And thus, it is not a matter of applying guano in soils and planting crop.

\section{The pH of Bat Guano}

References [32] and [33] observed that there is variation in $\mathrm{pH}$ between fresh and old guano deposits. Reference [34] reported that fresh guano is commonly basic, with the $\mathrm{pH}$ varying according to the volume of urine deposited with faeces. Fresh guano commonly had a $\mathrm{pH}$ of $8.5-9.0$ that rapidly became acidic (5.0 - 5.5) with age and depth, although the centre of guano piles had a stable $\mathrm{pH}$ of around 4. Reference[35] reported that guano contains high concentrations of nitrogen due to this, the $\mathrm{pH}$ of soil can be lowered if large quantities are applied to the soil over a long period of time because of building up of nitrogen levels in the soil. On the other hand, the acidification of soil due to exchangeable bases ( $\mathrm{Na}, \mathrm{Ca}, \mathrm{K}$ and $\mathrm{Mg}$ ) present in guano is very small this case causes the $\mathrm{pH}$ of soil to remain fairly constant. In a different way, [36] and [37] reported that fairly the addition of manure can cause an increase of $\mathrm{pH}$ in soil. Reference [38] also reported that water birds soils have higher $\mathrm{pH}$ due to less accumulation of guano and contain less N, P, and metals. 
Soil microbes are the source of decrease or increase in guano $\mathrm{pH}$. This is because the major waste products of decomposed organic matter and microbial growth are $\mathrm{CO}_{2}$, $\mathrm{CH}_{4}$, organic acid such as acetic and formic acids, and alcohol [18]. Formation of sulphuric acids due to the presence of elemental sulphur that has been oxidized by sulphur oxidizing bacteria lowers the guano $\mathrm{pH}$ [39]. Soil microbes, such as bacteria, are important agents in chemical changes in the guano. Their activities also result in the formation and accumulation of nitrate and sulphate salts [21], [39]. This increases the $\mathrm{pH}$ of the guano. Thus, the $\mathrm{pH}$ of guano should be determined at the time of application.

\section{Presence of Potentially Toxic Elements in Bat Guano}

Hazardous health effects of bat guano to the farmers who use bat guano as organic fertilizer include high risk of infection and can develop severe histoplasmosis [9], [40]. Rather than containing micronutrients such as $\mathrm{Zn}, \mathrm{Fe}, \mathrm{Mn}$ and $\mathrm{Cu}$ [8], [13] bat guano is the source of heavy metals like $\mathrm{Cd}, \mathrm{Co}, \mathrm{Ni}$ and $\mathrm{Pb}$ which can result in serious negative consequences, such as the loss of ecosystems and of agricultural productivity, the deterioration of food chain, contamination of water resources, economic damage, and serious health problems in humans and animals [41].

Most of bat guanos are acidic in nature [6], [42]. The challenge can be when applied to acidic soils, and the response of crop will not be efficient due to low $\mathrm{pH}$. Also, variability in their chemical composition, age, diet and chemistry of country rock can change the composition of guano. Thus, guano needs a thorough analysis before it is used by farmers including research on crop response, application rate based on crop and soil type which guano should be applied.

\section{Crop Responses to Bat Guano}

Many trials done by researchers have indicated that crops respond differently based on the amounts and source of guano applied to the soil [13], [14]. Some crops respond best when grown on soils applied guano at ratio of soil: guano of 20:1, 20:0.05 or 20:0.01. This implies that trials must be done to establish the appropriate amount of application before using any guano in crop production. For instances, [13] found the highest shoot length, total dry matter, nitrogen content and nitrogen uptake for finger millet (Eleusinecoracana) and legume (Phaseolusmungo) grown on red loamy soil applied guano at ratio of soil:guano of 20:1. Reference [14] studied the effect on the growth of Vignaradiata (mung bean) seedlings using guano from semi-carnivorous bats; the guano came from two different geographical locations (Varanga and Yennehole) applied in different quantities (soil: guano; 20:1, 20:0.5, 20:0.1) and in two types of soil (Autoclaved and Nonautoclaved). Plant growth assay indicated that guano from Yennehole was found to be better compared to that from Varanga. Amendment of both types of soil with bat guano from both locations showed good growth at soil: guano ratio of 20:0.5. Similarly, [25] in a pot experiment revealed significant $(\mathrm{p} \leq 0.05)$ increase in nutrients uptake from guano by maize with the increase in amounts of applied guano. However, the best plant performance was observed at ratio of 20:0.5. Higher application rates of $>20: 1$ caused poor maize response.

\section{REFERENCES}

[1] N. Sanginga and P.L. Woomer, Integrated Soil Fertility Management in Africa: Principles, Practices and Development Process. Tropical Soil Biology and Fertility Institute of the International Centre for Tropical Agriculture. Nairobi, Kenya. 2009, 263pp.

[2] P. Van Straaten, Rocks for Crops: Agro-minerals of Sub-Saharan Africa. International Centre for Research in Agroforestry, Nairobi, Kenya. 2002. 388pp.

[3] O.A. Olayiwola, "An assessment of the nitrogen, phosphorus and potassium level of some animal wastes as organic fertilizer source". Electronic J. Environ. Agric. Food Chemist., vol 10 issue 3, 2011 pp. $1973-1988$.

[4] FAO, Plant nutrition for food security. A guide for integrated nutrient management. FAO fertilizer and plant nutrition bulletin. 2006.

[5] D. Gillieson, Caves: Processes. Development and Management. Blackwell Publishing Limited, 1996, pp.203-236.

[6] R. Shahack-Gross, F. Berna , P. Karkanas and S. Weiner, "Bat guano and 1272 preservation of archaeological remains in cave sites". J. Archaeol. Sci., vol. 31, 2004, pp.1259-1272

[7] N.M. Furey and P.A. Racey, Conservation ecology of cave bats. In Bats in the Anthropocene: Conservation of bats in a changing world. Springer International Publishing, 2016, pp. 463-500

[8] O. Sikazwe, and B. de Waele, Assessment of the quality and reserves of Bat Guano at Chipongwe and Kapongo caves near Lusaka as fertilizer materials. Journal of Science and Technology (special edition), 2004, pp. 32-42

[9] N. Allocati, A.G. Petrucci, P. Di Giovanni, M. Masulli, C. Di Ilio, and V. De Laurenzi,"Bat-man disease transmission: Zoonotic pathogens from wildlife reservoirs to human populations". Cell Death Discov., vol. 2, 2016 pp 16048.

[10] J. G. Boyles, P. M. Cryan, G. F. McCracken and T. H. Kunz, "Economic importance of bats in agriculture". Sci., vol.332, issue 6025, 2011, pp. 41-42.

[11] S. Docampo, M.M. Trigo, M. Recio, M. Melgar, J. García-Sánchez and B. Cabezudo, "Fungal spore content of the atmosphere of the cave of Nerja (southern Spain): diversity and origin". Science Total Environ. vol.409, issue 4, 2011, pp. 835 -843.

[12] A.M.Nieves-Rivera, C.J. Santos-Flores, F.M. Dugan and T.E. Miller, "Guanophilic fungi in three caves of southwestern Puerto Rico". Intern. J. Speleology, vol.38, issue 1, 2009, pp. $61-70$.

[13] K.R. Sridhar, K.M. Ashwini, S. Seena and K.S. Sreepada, "Manure qualities of guano of insectivorous bat Hipposiderosspeoris". Tropical and Subtropical Agroecosy. vol.6, 2006, pp.103-110.

[14] S. Shetty, K.S. Sreepada and R. Bhat, "Effect of bat guano on the growth of Vignaradiata L." Intern. J. Scient. Research vol.3, issue 3, 2013, pp. $2250-3153$.

[15] P.M. Mlay and F. Sagamiko, "The use of bat guano in the improvement of the nutritive value of poor quality roughage fed to ruminants in Tanzania". Veter. archive, Vol. 78, 2008, pp. 417-427.

[16] G. F. McCracken and M.K. Gustin, "Bat mom's nightmare". Natural History vol.96, issue 101987 , pp. $66-73$.

[17] E. H Studierz, D. P. Viele and S. H. Sevick, "Nutritional implications for nitrogen and mineral budgets from analysis of guano of the big brown bat Eptesicusfuscus (Chiroptera: Vespertilionidae)". Comparative Biochem. Physiol., vol. 100, 1991, pp. 1035 - 1039.

18] P. L. Gile, and J. O. Carrero, "The bat guanos of Porto Rico and their fertilizing value". Porto Rico Agric. Exper. Station. Vol. 25, 1918, pp. $1-66$.

[19] L. Quattropani, L. Charlet, H. De Lumley and M. Menu, "Early Paleolithic bone diagenesis in the Arago cave at Tautavel, France". Mineral. Magazine, vol. 63, 199, pp. $801-812$.

[20] L. J. Maher, "Environmental information from guano palynology of insectivorous bats of the central part of the United States of America". Palaeogeogr., Palaeoclimatol. Palaeoecol., vol. 237, 2006, pp. $19-31$.

[21] C. A Hill, and P. Forti, "Cave Minerals of the World". 2nd Ed., National Speleological Society Inc., Huntsville, Alabama, 1997, pp. 
464.

[22] A. Giurgiu and T. Tămaş, "Mineralogical data on bat guano deposits from three Romanian caves". Studia Universitatis Babes-Bolyai Geologia, vol. 58, issue 2, 2013, pp. 13-18.

[23] H.R. Bhat and M.A Sreenivasan,. "Records of bats in Kyasanur forest disease area and environs in Karnataka State, India with ecological notes". Mammalia, vol. 54, 1990, pp.69-106.

[24] C. I. Korine, and Z. Arad, "Is the Egyptian fruit bat Rousettusa egyptiacusa pest in Israel? An analysis of the bat's diet and implications for its conservation”. Bioconservation, vol. 88, 1999, pp.301-306.

[25] T. Andrew, Characterization of Sukumawera and Kisarawe bat guano from Tanzania as soil amendment and source of plant nutrients. Unpublished MSc Dissertation Sokoine University of Agriculture, Morogoro, Tanzania, 2016 pp.30-38.

[26] P. Ross, Top sources of organic manure and its effectiveness. Oregon State University. Extention in Horticulture. 2003, pp. 1-4.

[27] J.M. Timothy, A.E Gray and W.H. Robert, "Food habits, occurrence and population structure of the bat ray Myliobatis Californica, in Humboldt Bay, California". Environ. Biol. fishes, vol. 49, issue 2, 2004, pp.227-238.

[28] S.P. Mathur, N.K. Patani and M.P. Levesque, "Static pile passive aeration composting of manual slurries using peat as bulking agent". Biol. Wastes, vol. 34: 1990, pp.232-333.

[29] J. K. Emerson and A. M Roark, "Composition of guano produced by Frugivorous, Sanguivorous, and Insectivorous bats". Acta Chiropterologica, vol. 9, issue 1, 2007, pp.261-267.

[30] M. Bird, E. Boobyer, C. Bryant, H. Lewis, V. Paz and W. Stephens, "A long record of environmental change from bat guano deposits in Makangit Cave, Palawan, Philippines". Earth and Envir. Sci. Trans. Royal Society of Edinburgh, vol. 98, issue 1, 2007, pp. 59-69.

[31] A.A Hatibu, (2018). Assessment of bat guano as source of nutrients for rice production. Unpublished MSc dissertation. Sokoine University of Agriculture. 2018, pp.100.

[32] V. Decu, "Bat guano ecosystem a new classification and some considerations with special references to neotropical data". Research in Experimental Biology. Cubano roumaines Cuba.1981, pp. 9-15.

[33] V. Decu, Some considerations on the bat guano synusia. Travaux de l'Institute de Spéologie "Emile Racovitza" vol. 25, 1986, pp. 41-51.

[34]J.A. Harries, "Bat guano cave environment". Science, vol. 169, 1970, pp.1342-1343.
[35] J. Barrett, FCS Soil Science L3. Pearson South Africa., 2008, pp. 69.

[36] B. Eghball, "Soil properties as influenced by phosphorus nitrogenbased manure and compost applications". Agron. J., vol. 94, 2002, pp.128-135.

[37] F. Iyamuremye, R.P. Dick and J. Baham "Organic amendments and Soil phosphorous dynamics: 1 . Phosphorus chemistry and sorption". Soil Sci., vol. 161, 1996, pp.426-435.

[38] C. R Ayers, K. C. Hanson, S. O'Dell, C.D. Lovell, M.L. Jones, J.R. Suckow and B. S. Dorr, "Impacts of colonial waterbirds on vegetation and potential restoration of island habitats". Restoration Ecol., vol. 23, issue 3, 2015, pp. 252-260.

[39] D.E. Northup, A.L Reysenbach, and N. R. Pace, (1997). Microorganisms and speleothems. In: Cave Minerals of the World, C. Hill, and P. Forti, Eds., 1997.

[40] L. Santos, G. Santos-Martinez, J.E. Magana-Ortiz and S.L. PuentePinon, "Acute histoplasmosis in three Mexican sewer workers". Occupational Medicine Landon J., vol. 63, 2013, pp. 77-79.

[41] I. Aydin, F. Aydin, A. Saydut, E.G. Bakirdere, and C. Hamamci, "Hazardous metal geochemistry of sedimentary phosphate rock used for fertilizer". Microchem. J., vol. 96, issue 2, 2010, pp. 247-251.

[42] N.R. Rebollo, I. Cohen-Ofri, R. Popovitz-Biro, O. Bar-Yosef, L. Meignen, P. Goldberg and E. Boaretto, "Structural characterization of charcoal exposed to high and low $\mathrm{pH}$ : implications for ${ }^{14} \mathrm{C}$ sample preparation and charcoal preservation". Radiocarbon, vol. 50, issue 2, 2008, pp. 289-307.

\section{Ernest Melkiory Marwa ${ }^{{ }^{*}}$, Twisege Andrew ${ }^{2}$ and Asha Ally Hatibu ${ }^{3}$}

${ }^{1}$ Department of Soil and Geological Sciences, College of Agriculture, Sokoine University of Agriculture, P.O. Box 3008, Morogoro, Tanzania *Corresponding author, Mobile no. +255 757577351 .

${ }^{2}$ Tanzania Coffee Research Institute (TaCRI), Lyamungu. P.O. Box 3004, Moshi, Tanzania. Mobile no. +255 755625031

${ }^{3}$ Asha Ally Hatibu, Tanzania Agriculture Research Institute (TARI), Naliendele, P.O. Box 509, Mtwara, Tanzania. Mobile no. +255 653040450 . 


\section{Profiles}

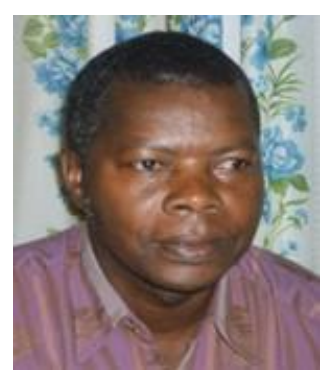

Name \& Contact: Eng. Prof. Ernest Melkiory Marwa $(\mathrm{PhD})$, Sokoine University of Agriculture, P.O. Box 3008, Morogoro, Tanzania. Email address: emarwa@sua.ac.tz

Academic Qualifications: BSc. (Geology) (UDSM), Postgraduate Diploma (Eng. Geology) (ITC-Delft), MSc. (Eng. Geology) (ITC-Delft), PhD (Soil \& Plants) (Aberdeen)

Research Interests: Soil amendment, Heavy metals in Soils, Mineral Exploration; and Geotechnical Investigations

\section{Research Experience}

- Project Leader: Nitrogen bio-fortified and pelletized commercial grade organic fertilizer made from urban biowaste to improve soil productivity and livelihoods of smallholder farmers. Project No: BA/C1/2017-05_SUA Sponsored by BioInnovate Africa through ICIPE at a cost of US $\$ 88,278$. Implemented from 1/1/2018-30/6/2021.

- Project Member: Mineral Resources Potential and Small Scale Mining in Nachingwea Area and a General Nationwide Geochemical Map of Tanzania. Research sponsored by Ministry of Foreign Affairs of Finland from 2015-2017

- Project Member: Analysis of stakeholders and formulation of innovation platform for optimizing production and utilization of lesser-known and lesserutilized indigenous agro-forestry timber species in Kilosa District. Project sponsored by NORAD under EPINAV project at SUA from 2013-2015.
- Project Leader: Effect of uranium contamination in selected Tanzanian agricultural soils and its transfer in food chains. Sponsored by RUFORUM at a cost of US\$ 49,019.25. Implemented from 1/10/2011-30/9/2013.

\section{Selected Recent Publications}

- Hatibu, A.A, Shitindi, M.J. and Marwa, E. M.M. (2020). Assessment of phosphorous release from bat guano with respect to their use as organic fertilizers in crop production. International Journal of Advances in Scientific Research and Engineering (ijasre), 6 (11): 99112. DOI: $10.31695 /$ IJASRE.2020.33894.

- $\quad$ Shi, Z., Carey, M., Meharg, C., Williams, P., Marwa, E. et al., (2020). Rice grain cadmium concentrations in the global supply-chain. Exposure and Health. https://doi.org/10.1007/s 12403-020- 00349-6

- $\quad$ Marwa, E. M.M., Meharg, A. A., and Rice, C.M. (2012): Risk assessment of potentially toxic elements in agricultural soils and maize tissues from selected districts in Tanzania. Science of the Total Environment, 416:180-186.

- Primitiva, A. M., Marwa, E. M. M. and Kaaya, A.K. (2018). Characterization of selected gypsites of Tanzania for agricultural use. International Journal of Plant \& Soil Science, 23(4): 1-9

- Kaishwa, S.J., Marwa, E.M., Msaky and Mwakalasya, W.N. (2018): Uranium natural levels in soil, rock and water: assessment of the quality of drinking water in Singida Urban District, Tanzania. Journal of Water and Health, 16.4:542-548.

- $\quad$ Sirikare, N.S., Naramabuye, F.X., Marwa, E.M. and Semu, E. (2015): Proton consumption capacity, ash alkalinity and chemical characterization of travertine from different sources in Rwanda. African Journal of Agriculture, 2 (1):070-075. 


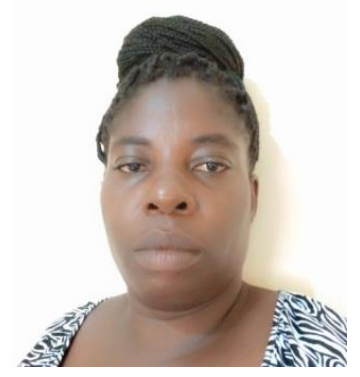

Ms. Andrew Twisege, Tanzania Coffee Research Institute, Lyamumgu, P. O. Box 3004, Moshi, Tanzania. Email: twisemwakabuta@yahoo.com

Ms. Andrew Twisege is a holder of MSc. Degree in Soil Science and Land Management and BSc. Degree in Agronomy from Sokoine University of Agriculture, Department of Soil and Geological Sciences. She is a researcher on soil-crop related researches in Tanzania Coffee Research Institute (TaCRI). She is also working as an Extension Agronomist at the Department of Technology Transfer at TaCRI Headquarter Moshi, Kilimanjaro. She is a member of Soil Science Society of East Africa (SSSEA).

She has unpublished one MSc dissertation titled "Characterization of Sukumawera and Kisarawe bat guano from Tanzania as soil amendment and source of plant nutrients", A Dissertation Submitted in Partial Fulfillment of the Requirements for the Degree of Master of Science in Soil Science and Land Management of Sokoine University of Agriculture Morogoro, Tanzania. 


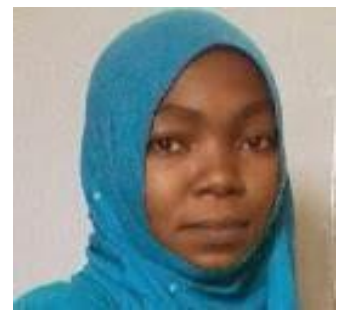

\section{Name \& Contact Address}

Asha Ally Hatibu, TARI Naliendele, P.O. Box 509, Mtwara, Tanzania.

Email: ashaally86@gmail. Com

\section{Academic Qualifications}

MSc Soil science and land

Management

B.Sc. (Agronomy)

Certificate of Advance level

Certificate of Secondary education

\section{Employment record}

Internship at TARI-Mlingano from 2018-2019,

Field officer at Royal Agric Co. Ltd in Tanzania from 2019-2020,

Seed Scientist at ICRISAT, TARI Naliendele from 2020 to date

\section{Publications}

Assessment of Phosphorous Release from Bat Guano with Respect to Their use as Organic Fertilizer in Crop Production" which was published in International
Journal of Advances in Scientific Research and Engineering (IJASRE) November 2020.

Assessment of bat guano as source of nutrients for rice production. Unpublished Msc dissertation, Sokoine University of Agriculture.

\section{Memberships}

Tanzania Agronomy Society (TAS) since October 2013

Organization for Women in Science for the Developing

World (OWSD) since February 2019

\section{Researches Explored}

Research in bat guano as organic fertilizer in rice production.

Research in Soil Fertility in south (Mtwara and Lindi) and southern highland zones (Ruvuma Njombe, and Songwe) of Tanzania.

Research in Seed systems specifically in leguminous crops (groundnuts) and cereal crops (Sorghum and finger millet) in Tanzania.

Research in public, private and developmental organizations partnerships in seed system. 